\title{
ПЕРЕВАРИМОСТЬ И УСВОЕНИЕ ПИТАТЕЛЬНЫХ ВЕЩЕСТВ КОРМА У РЕМОНТНОГО МОЛОДНЯКА КУР ПОД ДЕЙСТВИЕМ КОМПЛЕКСНОЙ МИНЕРАЛЬНОЙ ДОБАВКИ
}

\author{
V.A. Tereshchenko, T.A. Poleva
}

\section{THE DIGESTIBILITY AND DIGESTION OF FEED NUTRIENTS IN REPLACEMENT CHICKENS UNDER THE INFLUENCE OF COMPLEX MINERAL ADDITIVE}

Терещенко Вера Александровна - науч. сотр. отдела кормления и технологии кормов Красноярского НИИ животноводства - обособленного подразделения ФИЦ КНЦ СО РАН, асп. каф. зоотехнии и технологии переработки продуктов животноводства Красноярского государственного аграрного университета, г. Красноярск.

E-mail: v.a.tereshencko@mail.ru

Полева Татьяна Александровна - канд. биол. наук, доц. каф. зоотехнии и технологии переработки продуктов животноводства Красноярского государственного аграрного университета, г. Красноярск.

E-mail: atlantika_058@mail.ru

Цель исследований - изучение переваримости и усвоения питательных веществ кормосмесей ремонтным молодняком кур под влиянием скармливания разных дозировок комплексной минеральной кормовой добавки «ТоксиНон». Научно-хозяйственный опыт проводился в 000 «Боготольская птищефабрика» Боготольского района Красноярского края на ремонтном молодняке кур кросса Хайсекс коричневый. Было ссрормировано пять групп молодняка (контрольная и четыре опытных) в возрасте 10 недель по 70 голов в каждой группе. Продолжительность опыта составляла 70 дней. Согласно схеме опыта, контрольной групnе птицы скармливался основной рацион, 1-й опытной группе дополнительно к основному рациону скармливалась кормовая добавка «ТоксиНон» в дозировке 0,05 \% от массы кормосмеси; 2-й - 0,15; 3-й - 0,25; 4-й опытной групnе - 0,35 \%. Исследования и обработка данных проведены по общепринятым методикам. В результате исследований установлено, что скармливание кормовой добавки «Токси-
Tereshchenko Vera Alexandrovna - Staff Scientist, Department of Feeding and Technology of Forages, Krasnoyarsk Scientific Research Institute of Animal Husbandry - Separate Division of FRC KRC SB RAS, Post-Graduate Student, Chair of Animal Breeding and Technology of Livestock Products Processing, Krasnoyarsk State Agrarian University, Krasnoyarsk.

E-mail: v.a.tereshencko@mail.ru

Poleva Tatyana Alexandrovna - Cand. Biol. Sci., Assoc. Prof., Chair of Animal Breeding and Technology of Livestock Products Processing, Krasnoyarsk State Agrarian University, Krasnoyarsk.

E-mail: atlantika_058@mail.ru

Нон» положительно повлияло на переваримость и усвоение питательных веществ кормосмесей ремонтного молодняка кур, однако наиболее эфффрективно питательные вещества переваривались и усваивались при скармливании кормовой добавки в дозировке $0,25 \%$ от массы кормосмеси (3-я опытная групnа): переваривание сухого вещества у молодняка этой группы увеличилось на 2,4 \% $(P<0,05)$; органического вещества - на 3,10 ( $P<0,05)$; сырого протеина - на 1,80; сырого жира - на 1,75; сырой клетчатки - на 0,50; усвоение азота - на 4,68; кальция - на 2,98; фоосфора - на 9,87 \%. Полученные результаты исследований позволяют считать кормовую добавку «ТоксиНон» 8 дозировке 0,25 \% от массы кормосмеси наиболее эфффективной для скармливания ремонтному молодняку кур.

Ключевые слова: ремонтный молодняк кур, переваримость питательных веществ, кормовая добавка, «ТоксиНон», кормление, азот, кальщий, фросфрор. 
The purpose of the research was studying the digestibility and nutrition absorption of feed mixture by repair young growth of hens under the influence of feeding different dosages of complex mineral ToksiNon feed additive. Scientific and economic experiment was made in JSC 'Bogotolsky Poultry Farm' of Bogotolsky area, Krasnoyarsk Region on repair young growth of hens of Highsex Brown cross. Five groups of young growth (control and four experimental) at the age of 10 weeks up to 70 heads in each were created. The duration of the experiment made 70 days. According to the scheme of the experiment, control group of the poultry was fed with the main diet, to the 1-st experimental group in addition to the main diet ToksiNon feed additive in a dosage of $0.05 \%$ of the mass of feed mixture was fed; the 2-nd - 0.15; the 3-rd 0.25 ; to the 4-th experimental group $-0.35 \%$. The researches and data processing were carried out by the standard techniques. As a result of the researches it was established that feeding with ToksiNon feed additive positively affected the repair young growth of hens' digestibility and digestion of nutrients feed mixture, however, most effectively nutrients were digested and acquired when feeding feed additive in a dosage of $0.25 \%$ of the mass of feed mixture (the 3-rd experimental group): digestion of solid at young growth of this group increased by $2.4 \%(R<0.05)$; organic substance - on 3.10 ( $R$ $<0.05)$; crude protein - on 1.80; crude fat - on 1.75; crude fiber - on 0.50; digestion of nitrogen - on 4.68; calcium - on 2.98; phosphorus - for $9.87 \%$. The results received in the researches allow considering ToksiNon feed additive in a dosage of 0.25 $\%$ of the mass of feed mixture to be the most effective one for feeding repair young growth of hens.

Keywords: replacement chickens, digestibility of nutrients, feed additive, "ToksiNon", feeding, nitrogen, calcium, phosphorus.

Введение. Основой реализации генетически обусловленного потенциала продуктивности сельскохозяйственной птицы и эффрективного производства продуктов птицеводства является полноценное сбалансированное кормление [1-3].

Полноценным считается кормление, при котором в соответствии с потребностями организма птица получает все необходимые жизненно важные питательные и биологически активные вещества $[4,5]$.
Кормосмеси для птицы должны содержать не только оптимальный уровень обменной энергии, протеина, но и комплекс макро- и микроэлементов, витаминов, которые играют роль катализаторов в обмене веществ и энергии [6].

Несбалансированное кормление, которое не соответствует принятым детализированным нормам, - основная причина задержек роста и развития, снижения продуктивности птицы [7].

В современное время с целью балансирования рационов, повышения усвояемости питательных веществ, снижения токсичности и бактериальной загрязненности ингредиентов кормов разрабатывают и применяют различные кормовые добавки $[8,9]$.

Перспективными для птицеводства и безопасными кормовыми добавками являются такие соединения, которые созданы на основе природного сырья [10], в частности на основе природных минералов.

В данных исследованиях изучалась кормовая добавка «ТоксиНон» (производство ООО «БИОРОСТ», Россия), представляющая собой экологически чистый комплекс минералов природного происхождения (бентонит очищенный до $84 \%$, цеолит - до $18 \%$, диоксид кремния до $3 \%$ ). Добавка имеет богатый минеральный состав ( $\mathrm{SiO}_{2} ; \mathrm{Al}_{2} \mathrm{O}_{3} ; \mathrm{Fe}_{2} \mathrm{O}_{3} ; \mathrm{CaO} ; \mathrm{MgO} ; \mathrm{MnO} ; \mathrm{K}_{2} \mathrm{O}$; $\left.\mathrm{Na}_{2} \mathrm{O} ; \mathrm{TiO}_{2}\right)$, благодаря которому позволяет обогащать кормосмеси макро- и микроэлементами, необходимыми для поддержания метаболизма в организме [11]. Входящие в состав добавки природные минералы обладают высокой адсорбционной, каталитической, ионообменной активностью, что позволяет адсорбировать и выводить различные вредные вещества (тяжелые металлы, радионуклиды, микотоксины, нитраты, нитриты, патогенные микроорганизмы, вирусы, и другие) из организма, нормализовать процесс пищеварения и способствовать сохранению иммунитета птицы.

При проведении научных $и$ научнопроизводственных исследований по кормлению сельскохозяйственной птицы, в частности по скармливанию различных кормовых добавок, важным условием является изучение переваримости и усвоения питательных веществ организмом [12-14]. 
Цель исследований: изучение переваримости и усвоения питательных веществ кормосмесей ремонтным молодняком кур под влиянием скармливания разных дозировок комплексной минеральной кормовой добавки «ТоксиНон».

В задачи исследований входило:

1. Рассчитать коэфффициенты переваримости питательных веществ кормосмесей ремонтным молодняком кур.

2. Рассчитать баланс усвоения азота, кальция и фоссрора ремонтным молодняком кур.

Материал и методы исследований. Для проведения исследований в условиях 000 «Боготольская птицефабрика» Боготольского района Красноярского края по методу группаналогов (с учетом кросса, возраста, живой массы и общего развития) было сформировано пять групп (контрольная и четыре опытных) ремонтного молодняка кур кросса Хайсекс коричневый в возрасте 10 недель, по 70 голов в каждой группе. Эксперимент продолжался 70 дней.

Птицу содержали в цехе ремонтного молодняка в клеточных батареях КБУ-3 (по 10 голов в клетке) с соблюдением принятых технологических параметров, рекомендованных для молодняка кросса [15].

Согласно схеме опыта (табл. 1), на протяжении исследований контрольной группе скармливался основной рацион, молодняку 1-й, 2-й, 3-й и 4-й опытных групп дополнительно к основному рациону скармливалась кормовая добавка «ТоксиНон» в количестве 0,05; 0,15; 0,25; 0,35 \% от массы кормосмеси соответственно.

Таблица 1

\section{Схема опыта}

\begin{tabular}{|l|c|c|c|}
\hline Группа & $\begin{array}{c}\text { Кол-во голов } \\
\text { в группе }\end{array}$ & $\begin{array}{c}\text { Продолжительность } \\
\text { опыта, дней }\end{array}$ & $\begin{array}{c}\text { Особенности } \\
\text { кормления }\end{array}$ \\
\hline Контрольная & 70 & 70 & Основной рацион (ОР) \\
\hline 1-я опытная & 70 & 70 & ОР + «ТоксиНон» $(0,05 \%)$ \\
\hline 2-я опытная & 70 & 70 & ОР + «ТКсиНон» $(0,15 \%)$ \\
\hline 3-я опытная & 70 & 70 & ОР + «ТоксиНон» $(0,25 \%)$ \\
\hline 4-я опытная & 70 & 70 & ОР + «ТоксиНон» $(0,35 \%)$ \\
\hline
\end{tabular}

Примечание. Дозировка кормовой добавки приведена в \% от массы кормосмеси.

Кормление подопытной птицы осуществлялось по принципу фазового кормления, два раза в сутки вволю сухими полнорационными кормосмесями, сбалансированными согласно рекомендациям ВНИТИП (2003 г.) и Руководству по содержанию и кормлению кросса (2011 г.). На каждой стадии развития птицы молодняку скармливалась кормосмесь разных рецептур и питательности: с 10-16 недель возраста - кормосмесь «Развитие» (обменной энергии - 1,19 МДж, сырого протеина - 17,42 \%; сырой клетчатки - 4,96; сырого жира - 5,45; кальция - 1,17; фосффора доступного - 0,44; фоссфора общего 0,66 \%); с 17-20 недель возраста - кормосмесь «Предкладка» (обменной энергии - 1,15 МДж, сырого протеина - 16,80 \%; сырой клетчатки 6,25; сырого жира - 8,10; кальция - 2,10; фоосфора доступного - 0,42; фоссфора общего - 0,60 $\%$ ). Исследуемую добавку вводили в кормосмеси методом ступенчатого смешивания.
Для изучения переваримости и использования питательных веществ кормосмесей в конце периода выращивания проводили балансовый опыт в соответствии с методикой ВНИТИП (2013). Из каждой группы было отобрано по 5 голов молодняка кур, которых содержали в индивидуальных клетках с сетчатым полом и установленными поддонами, покрытыми полиэтиленовой пленкой для сбора помета. Балансовый опыт проводили в два периода: предварительный (5 дней) и учетный (3 дня). На протяжении физиологического опыта ежедневно индивидуально по каждой птице учитывали количество съеденного корма, его остатков и количество выделенного помета. По окончании балансового опыта средние пробы помета и остатков корма подвергали фризиологобиохимическим исследованиям: определяли количество сухого вещества - по ГОСТ 31640-2012; содержание влаги (первоначальной влаги, гигроско- 
пической) - по ГОСТ Р 54951-2012; сырой клетчатки - по ГОСТ 31675-2012; сырого жира - по ГОСТ 32905-2014; общего азота и сырого протеина - по ГОСТ 32044.1-2012; сырой золы - по ГОСТ 32933-2014; кальция - по ГОСТ 26570-95; фоссфора - по ГОСТ 26657-97.

По результатам анализов вычисляли количество питательных веществ, потребленных птицей с кормом, и количество веществ, выделенных с пометом. По разности между данными показателями рассчитывали количество переваренных питательных веществ. Коэфффициенты переваримости, балансы азота, кальция и фосфора вычисляли по общепринятым методикам [16].
Биометрическую обработку цифровых опытных данных проводили по методике Н.А. Плохинского (1969) в компьютерной программе «Пакет анализа для биометрической обработки зоотехнических данных» (КрасНИИЖ, 2015). Достоверность разности между группами устанавливали по критерию Стьюдента в пределах следующих уровней значимости: ${ }^{*} \mathrm{p}<0,05$; ${ }^{* *} p<0,01 ;{ }^{* * *} p<0,001$.

Результаты исследований и их обсуждение. В таблице 2 представлены коэффициенты переваримости питательных веществ корма подопытным ремонтным молодняком кур.

Коэфффициенты переваримости питательных веществ

Таблица 2 подопытным ремонтным молодняком, \% (M $\pm m, n=5)$

\begin{tabular}{|l|c|c|c|c|c|}
\hline \multirow{2}{*}{ Показатель } & \multicolumn{5}{|c|}{ Группа } \\
\cline { 2 - 6 } & Контрольная & 1-я опытная & 2-я опытная & 3-я опытная & 4-я опытная \\
\hline $\begin{array}{l}\text { Сухое } \\
\text { вещество }\end{array}$ & $71,80 \pm 0,62$ & $72,62 \pm 1,00$ & $73,08 \pm 1,28$ & $74,23 \pm 0,51^{*}$ & $72,79 \pm 0,52$ \\
\hline $\begin{array}{l}\text { Органическое } \\
\text { вещество }\end{array}$ & $74,24 \pm 1,09$ & $74,51 \pm 1,24$ & $75,67 \pm 0,81$ & $77,29 \pm 0,76^{*}$ & $76,26 \pm 1,02$ \\
\hline $\begin{array}{l}\text { Сырой } \\
\text { протеин }\end{array}$ & $85,45 \pm 0,83$ & $85,95 \pm 0,88$ & $86,29 \pm 0,61$ & $87,22 \pm 0,83$ & $85,67 \pm 0,67$ \\
\hline Сырой жир & $94,53 \pm 1,15$ & $94,11 \pm 1,28$ & $95,24 \pm 0,78$ & $96,28 \pm 0,79$ & $95,55 \pm 0,88$ \\
\hline $\begin{array}{l}\text { Сырая } \\
\text { клетчатка }\end{array}$ & $19,73 \pm 1,23$ & $19,52 \pm 1,11$ & $20,03 \pm 0,90$ & $20,21 \pm 1,06$ & $20,13 \pm 0,76$ \\
\hline
\end{tabular}

Наиболее высокими коэфффициентами переваримости отличался молодняк 3-й опытной группы, дополнительно получавший 0,25 \% «ТоксиНон». По сравнению с контролем переваривание сухого вещества в 3-й опытной группе было больше на 2,4 \% (P<0,05), органического вещества - на $3,10 \%$ ( $<<0,05)$, сырого протеина - на 1,80 \%, сырого жира - 1,75 \%, сырой клетчатки - на 0,50\%.

Из данных рисунка 1 видно, что наиболее высокие коэффициенты переваримости были отмечены по сырому жиру, наиболее низкие по сырой клетчатке.

В таблице 3 представлен баланс и использование азота подопытным ремонтным молодняком кур.
Баланс усвоения азота молодняком кур был положительным во всех группах. По сравнению с контрольной группой молодняк опытных групп лучше использовал азот, в 1-й, 2-й и 3-й опытных группах на 0,52; 2,81; 4,68 \% соответственно. Это свидетельствует о том, что скармливание кормовой добавки «ТоксиНон» ремонтному молодняку кур способствует большему отложению белка корма в организм птицы. Молодняк 4-й опытной группы по использованию азота отставал от контрольной группы на 0,22 \%.

В обменных процессах организма птицы существенную роль играют минеральные вещества. В таблице 4 представлен баланс и использование кальция подопытным ремонтным молодняком кур. 


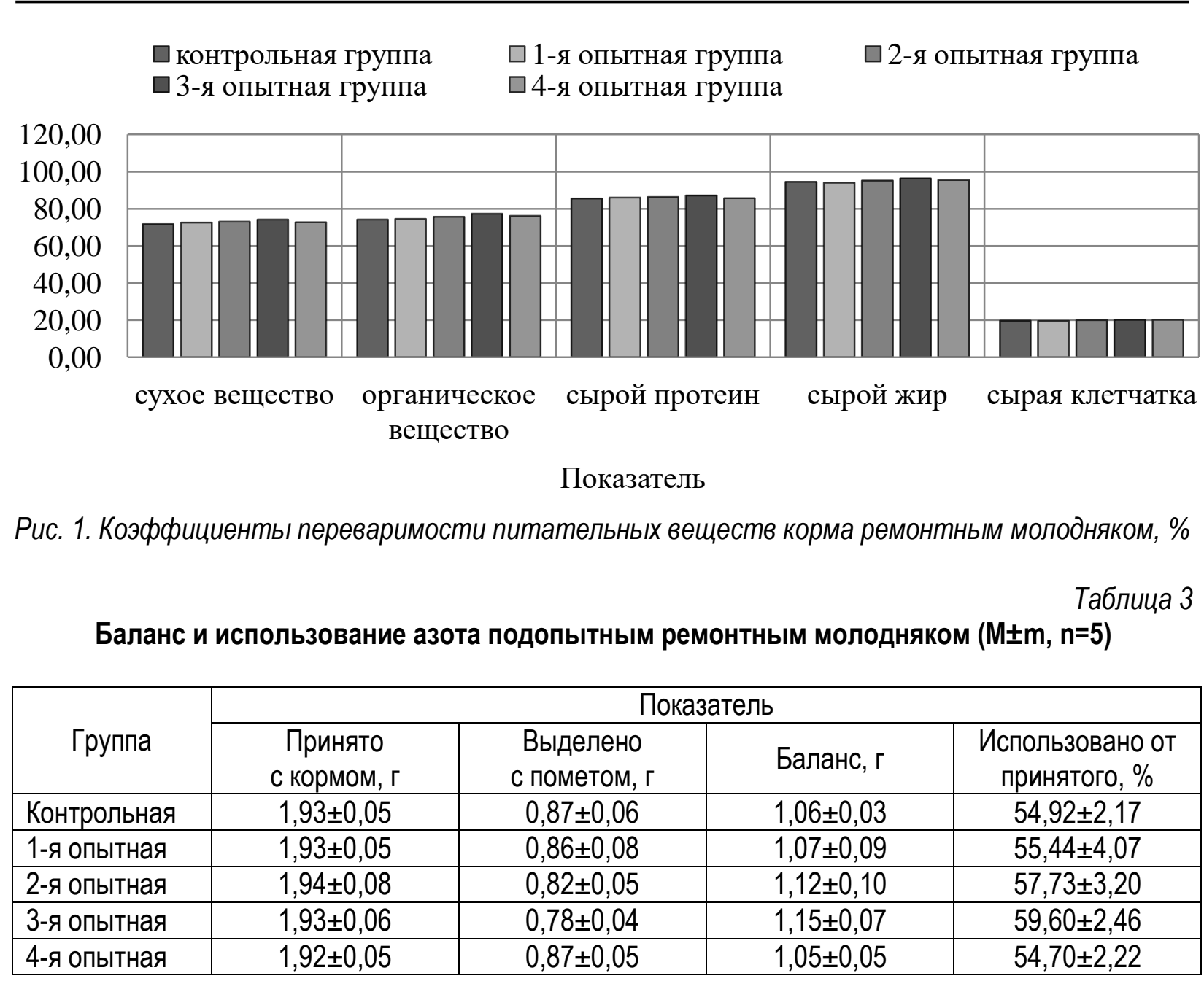

Таблица 4

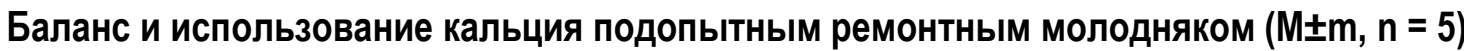

\begin{tabular}{|l|c|c|c|c|}
\hline \multirow{2}{*}{ Группа } & \multicolumn{4}{|c|}{ Показатель } \\
\cline { 2 - 5 } & $\begin{array}{c}\text { Принято } \\
\text { с кормом, г }\end{array}$ & $\begin{array}{c}\text { Выделено } \\
\text { с пометом, г }\end{array}$ & Баланс, г & $\begin{array}{c}\text { Использовано } \\
\text { от принятого, \% }\end{array}$ \\
\hline Контрольная & $1,86 \pm 0,06$ & $0,95 \pm 0,09$ & $0,91 \pm 0,10$ & $48,92 \pm 4,68$ \\
\hline 1-я опытная & $1,84 \pm 0,04$ & $0,93 \pm 0,08$ & $0,91 \pm 0,08$ & $49,45 \pm 4,05$ \\
\hline 2-я опытная & $1,84 \pm 0,07$ & $0,91 \pm 0,06$ & $0,93 \pm 0,03$ & $50,54 \pm 3,76$ \\
\hline 3-я опытная & $1,85 \pm 0,05$ & $0,89 \pm 0,07$ & $0,96 \pm 0,09$ & $51,90 \pm 4,29$ \\
\hline 4-я опытная & $1,86 \pm 0,06$ & $0,92 \pm 0,07$ & $0,94 \pm 0,13$ & $50,54 \pm 5,48$ \\
\hline
\end{tabular}

Баланс кальция во всех группах подопытной птицы был положительный и составлял 0,910,96 г. Молодняком 3-й опытной группы было больше использовано кальция, чем аналогами контрольной группы на 2,98 \%; 1-й опытной группы - на 2,45 \%; 2-й и 4-й опытных групп - на $1,36 \%$.

В таблице 5 представлен баланс и использование фоссфора подопытным ремонтным молодняком кур. 
Таблица 5

Баланс и использование фосффора подопытным ремонтным молодняком ( $\mathrm{M} \pm \mathrm{m}, \mathrm{n}=5)$

\begin{tabular}{|l|c|c|c|c|}
\hline \multirow{2}{*}{ Группа } & \multicolumn{4}{|c|}{ Показатель } \\
\cline { 2 - 5 } & $\begin{array}{c}\text { Принято } \\
\text { с кормом, г }\end{array}$ & $\begin{array}{c}\text { Выделено } \\
\text { с пометом, г }\end{array}$ & Баланс, г & $\begin{array}{c}\text { Использовано от } \\
\text { принятого, \% }\end{array}$ \\
\hline Контрольная & $0,51 \pm 0,04$ & $0,29 \pm 0,02$ & $0,22 \pm 0,03$ & $43,13 \pm 3,85$ \\
\hline 1-я опытная & $0,52 \pm 0,05$ & $0,27 \pm 0,03$ & $0,25 \pm 0,06$ & $48,10 \pm 7,29$ \\
\hline 2-я опытная & $0,52 \pm 0,06$ & $0,26 \pm 0,03$ & $0,26 \pm 0,06$ & $50,00 \pm 7,63$ \\
\hline 3-я опытная & $0,52 \pm 0,05$ & $0,24 \pm 0,03$ & $0,28 \pm 0,05$ & $53,84 \pm 6,06$ \\
\hline 4-я опытная & $0,51 \pm 0,05$ & $0,26 \pm 0,04$ & $0,25 \pm 0,06$ & $49,01 \pm 8,44$ \\
\hline
\end{tabular}

Птица опытных групп наиболее эсффективно усваивала фоссфор из кормосмесей по сравнению с аналогами контрольной группы: в 1-й опытной группе - на 4,97 \%; во 2-й - на 6,87; в 3-й - на 9,87; в 4-й опытной группе - на 6,71\%. Однако лучше всего фосффор усваивался птицей 3-й опытной группы $(53,84 \%)$.

Наибольшее отложение кальция и фосфрора в организме ремонтного молодняка кур опытных групп по сравнению с аналогами контроля может свидетельствовать о более интенсивном росте костной ткани - это является необходимым условием активного увеличения живой массы молодняка в период выращивания.

Выводы. На основании проведенных исследований можно сделать следующие выводы:

1. Скармливание комплексной минеральной кормовой добавки «ТоксиНон» положительно повлияло на переваримость и усвоение питательных веществ кормосмесей ремонтного молодняка кур.

2. Наиболее эфффективно питательные вещества переваривались и усваивались при скармливании кормовой добавки «ТоксиНон» в количестве $0,25 \%$ от массы кормосмеси: переваривание сухого вещества увеличилось на 2,4 $\%$; органического вещества - на 3,10 ; сырого протеина - на 1,80; сырого жира - на 1,75; сырой клетчатки - на 0,50; усвоение азота - на 4,68; кальция - на 2,98; фоссфора - на 9,87 \%.

\section{Литература}

1. Фисинин В., Егоров И., Мухина Н. и др. Нанотехнологии для профилактики микотоксинов в птицеводстве // Комбикорма. 2011. № 4. С. 63-64.

2. Кононенко С.И. Высокоэфффективный способ повышения продуктивности // Известия Горского государственного аграрного университета. 2016. № 1. С. 67-70.
3. Горковенко Л.Г., Осепчук Д.В., Петенко А.И. Ресурсосберегающие подходы к кормлению птицы // Политематический сетевой электронный научный журнал Кубан. гос. аграр. ун-та. 2016. № 115. С. 1-10.

4. Эккерт Л.Н. Эфффективность использования хакасских бентонитов в кормлении бройлеров кросса «HUBBARD» при разных способах выращивания: автореф. дис. ... канд. с.-х. наук: 06.02.08; 06.02.10. Красноярск, 2016. 16 с.

5. Терещенко В.А., Полева Т.А. Рост и развитие ремонтного молодняка кур-несушек при использовании адсорбента «ТоксиНон» // Вестник КрасГАУ. 2016. № 9 С. 206-212.

6. Иванова О.В. Влияние Викасола и пробиотиков на продуктивность цыплят-бройлеров: автореф. дис. ... канд. с.-х. наук: 06.02.02. Новосибирск, 2003. 24 с.

7. Краснощёкова Т.А., Нимаева В.Ц., Красильникова Н.В. Оптимизация кормления кур путем инактивации некрахмалистых полисахаридов в зерновых ингредиентах комбикормов марки ПК-1 и ПК-4 // Дальневосточный аграрный вестник. 2018. № 4 (48). C. 177-178.

8. Тлецерук И.Р., Чиков А.Е., Кононенко С.И. Комбикорма с нетрадиционными компонентами // Новые технологии. 2012. № 2. C. 109-111.

9. Кощаев А.Г., Хмара И.Н., Хмара И.В. Естественная контаминация зернофуража и комбикормов для птицеводства микотоксинами // Тр. Кубан. гос. аграр. ун-та. 2013. T. 3, № 42. C. 82-88.

10. Бабухадия К.P. Научное и практическое обоснование использования ламинарии японской в составе комбикормов для молодняка кур и кур-несушек: автореср. дис. ... д-ра с.-х. наук: 06.02.08. Курган, 2016. 35 с. 
11. Адсорбент микотоксинов «ТоксиНон» Биорост. URL: https://biorost.su/production/ kormovye-dobavki-/toksinon.

12. Астраханцев А.А. Переваримость и использование питательных и минеральных веществ кормосмесей у кур-несушек кроссов Родонит-2, Хайсекс коричневый и Хайсекс белый // Научный потенциал - современному АПК: мат-лы Всерос. науч.-практ. конф. Ижевск: Ижевская ГСХА, 2009. С. 7-11.

13. Трошина Т.А., Миронова Г.Н., Иванов И.С. [и др.] Биотики для здоровья и продуктивности животных // Научный потенциал - современному АПК: мат-лы Всерос. науч.практ. конф. Ижевск: Ижевская ГСХА, 2009. C. 149-152.

14. Хайсанов Д.П., Наумова В.В. Переваримость и использование питательных веществ скармливаемых рационов птицей кроссов Родонит и Бованс белый // Вестник Ульяновской гос. с.-Х. академии. 2004. № 15. С. 157-159.

15. Хайсекс Браун. Руководство по клеточному содержанию / Институт Селекции Животных БB; ISA. A Hendrix Genetics Company. Боксмеер, 2011. $32 \mathrm{c}$.

16. Методики определения переваримости кормов и рационов / под ред. М.Ф. Томмэ; Всесоюз. акад. с.-х. наук им. В.И. Ленина. M., 1969. 39 c.

\section{Literatura}

1. Fisinin V., Egorov I., Muhina N. i dr. Nanotehnologii dlja profilaktiki mikotoksinov $\mathrm{v}$ pticevodstve // Kombikorma. 2011. № 4. S. 63-64.

2. Kononenko S.I. Vysokojeffektivnyj sposob povyshenija produktivnosti // Izvestija Gorskogo gosudarstvennogo agrarnogo universiteta. 2016. № 1. S. 67-70.

3. Gorkovenko L.G., Osepchuk D.V., Petenko A.I. Resursosberegajushhie podhody k kormleniju pticy // Politematicheskij setevoj jelektronnyj nauchnyj zhurnal Kuban. gos. agrar. un-ta. 2016. № 115. S. 1-10.

4. Jekkert L.N. Jeffektivnost' ispol'zovanija hakasskih bentonitov v kormlenii brojlerov krossa «HUBBARD» pri raznyh sposobah vyrashhivanija: avtoref. dis. ... kand. s.-h. nauk: 06.02.08; 06.02.10. Krasnojarsk, 2016.16 s.

5. Tereshhenko V.A., Poleva T.A. Rost i razvitie remontnogo molodnjaka kur-nesushek pri ispol'zovanii adsorbenta «ToksiNon» // Vestnik KrasGAU. 2016. № 9. S. 206-212.

6. Ivanova O.V. Vlijanie Vikasola i probiotikov na produktivnost' cypljat-brojlerov: avtoref. dis. ... kand. s.-h. nauk: 06.02.02. Novosibirsk, 2003. $24 \mathrm{~s}$.

7. Krasnoshhjokova T.A., Nimaeva V.C., Krasil'nikova N.V. Optimizacija kormlenija kur putem inaktivacii nekrahmalistyh polisaharidov $\checkmark$ zernovyh ingredientah kombikormov marki PK-1 i PK-4 // Dal'nevostochnyj agrarnyj vestnik. 2018. № 4 (48). S. 177-178.

8. Tleceruk I.R., Chikov A.E., Kononenko S.I. Kombikorma s netradicionnymi komponentami // Novye tehnologii. 2012. № 2. S. 109-111.

9. Koshhaev A.G., Hmara I.N., Hmara I.V. Estestvennaja kontaminacija zernofurazha i kombikormov dlja pticevodstva mikotoksinami // Tr. Kuban. gos. agrar. un-ta. 2013. T. 3, № 42. S. 82-88.

10. Babuhadija K.R. Nauchnoe i prakticheskoe obosnovanie ispol'zovanija laminarii japonskoj v sostave kombikormov dlja molodnjaka kur $i$ kur-nesushek: avtoref. dis. ... d-ra s.-h. nauk: 06.02.08. Kurgan, 2016. $35 \mathrm{~s}$.

11. Adsorbent mikotoksinov «ToksiNon» - Biorost. URL: https://biorost.su/production/kormovyedobavki-/toksinon.

12. Astrahancev A.A. Perevarimost' i ispol'zovanie pitatel'nyh i mineral'nyh veshhestv kormosmesej u kur-nesushek krossov Rodonit-2, Hajseks korichnevyj i Hajseks belyj II Nauchnyj potencial - sovremennomu APK: mat-ly Vseros. nauch.-prakt. konf. Izhevsk: Izhevskaja GSHA, 2009. S. 7-11.

13. Troshina T.A., Mironova G.N., Ivanov I.S. i dr. Biotiki dlja zdorov'ja i produktivnosti zhivotnyh // Nauchnyj potencial - sovremennomu APK: mat-ly Vseros. nauch.-prakt. konf. Izhevsk: Izhevskaja GSHA, 2009. S. 149-152.

14. Hajsanov D.P., Naumova V.V. Perevarimost' i ispol'zovanie pitatel'nyh veshhestv skarmlivaemyh racionov pticej krossov Rodonit $i$ Bovans belyj // Vestnik Ul'janovskoj gos. s.-h. akademii. 2004. № 15. S. 157-159.

15. Hajseks Braun. Rukovodstvo po kletochnomu soderzhaniju / Institut Selekcii Zhivotnyh BV; ISA. A Hendrix Genetics Company. Boksmeer, 2011. $32 \mathrm{~s}$.

16. Metodiki opredelenija perevarimosti kormov i racionov / pod red. M.F. Tommje; Vsesojuz. akad. s.-h. nauk im. V.I. Lenina. M., 1969. $39 \mathrm{~s}$. 